\title{
Massive Micropropagation of Chilean Strawberry
}

\author{
M. Paredes ${ }^{1}$ \\ INIA, Centro Regional de Investigación Quilamapu, Casilla 426, Chillán, Chile
}

A. Lavín

INIA, Centro Experimental Cauquenes, Casilla 165, Cauquenes

\begin{abstract}
During the 20th century, cultivated strawberry (Fragaria $\times$ ananassa Duch.) replaced Chilean wild strawberry [Fragaria chiloensis (L.) Duch.] as a crop in Chile, even though the latest has a greater flavor and aroma and resistance to biotic traits (Crock et al., 1982; Daubeny and Pepin, 1965; Hancock et al., 1999; Shank and Baritt, 1974, 1984). However, the cultivated strawberry has higher fruit size, yield and a longer period of harvesting, due to the development of improved cultivars and the use of higher levels of inputs. The Experimental Research Center of INIA in Cauquenes, has a large germplasm collection of this specie (Cameron et al., 1993). From this collection, superior genotypes have been selected based on their high yield and fruit quality. To reach a commercial

(d) Rooting

level of production, it is necessary to produce a high number of plants. Clonal propagation through axillary bud proliferation has been used commercially (Boxus, 1998; Rosati, 1993), controlling the number of subcultures (Boxus et al., 2000; Damiano et al., 1995; Jungnickel, $1988)$ to avoid genetic unstability. The objective of this study was to develop an efficient micropropagation protocol to propagate selected clones of Chilean wild strawberry (Fig. 1).
\end{abstract}

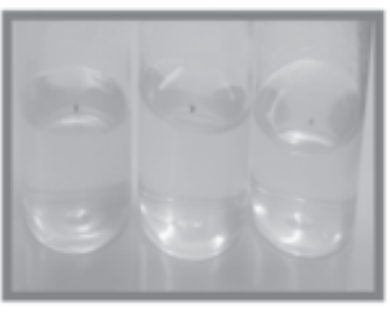

(a) Axillary buds

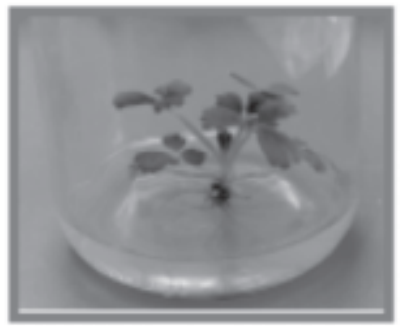

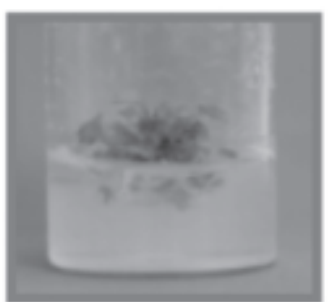

(b) Multiplication

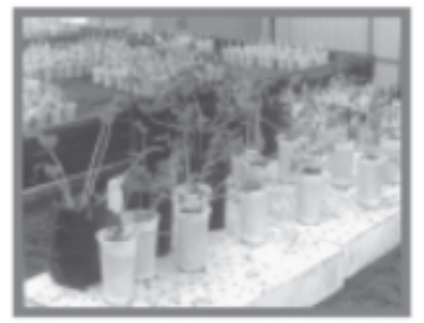

(e) Pre-acclimation

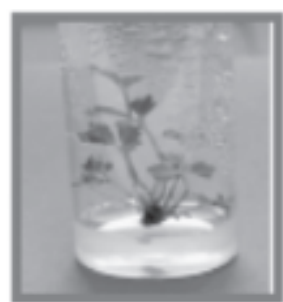

(c) Plantlet elongation

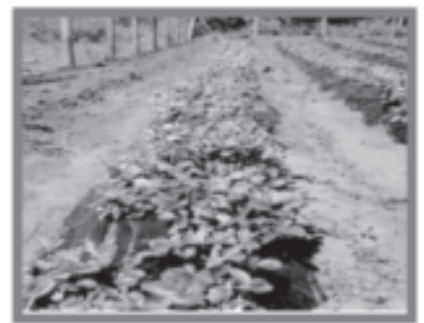

(d) Field establishment

\section{Materials and Methods}

Selected wild strawberry plants, grown in the greenhouse, served as mother plants for the excision of axillary bud. The surface sterilization of runner-tips to control fungal contamination consisted of an immersion in $70 \%$ alcohol, use of an antioxidant and sodium hypochlorite $(25 \%)$ for $15 \mathrm{~min}$ and rinsing of materials in sterile and distilled water. Axillary buds aseptically-isolated from runner tips and crowns (Fig. 1A), were cultured on agar-solidified MS nutrient medium modified with a low mineral content, and supplemented with IBA $\left(1.0 \mathrm{mg} \cdot \mathrm{L}^{-1}\right)$, BA $\left(0.1 \mathrm{mg} \cdot \mathrm{L}^{-1}\right)$ and $\mathrm{GA}_{3}\left(0.1 \mathrm{mg} \cdot \mathrm{L}^{-1}\right)$ and incubated at $25^{\circ} \mathrm{C}$ with $16 \mathrm{~h}$ photoperiods. Shoots differentiated were transferred to MS-agar medium, supplemented with IBA $\left(0.1 \mathrm{mg} \cdot \mathrm{L}^{-1}\right)$, BA $\left(0.5 \mathrm{mg} \cdot \mathrm{L}^{-1}\right)$ and $\mathrm{GA}_{3}\left(0.1 \mathrm{mg} \cdot \mathrm{L}^{-1}\right)$, and incubated under same conditions mentioned above, in order to induce mass proliferation of shoots (Fig. 1B). Plantlets

Financial support from PRODECOP.

'E-mail mparedes@inia.cl. were transferred to the MS-agar medium with a BA concentration of $0.1 \mathrm{mg} \cdot \mathrm{L}^{-1}$ for elongation and rooting (Fig. 1C and D). Rooted plants were transferred to a substrate under greenhouse conditions with a mist irrigation system and 20 to $25^{\circ} \mathrm{C}$ (Fig. 1E) and transferred to the field (Fig. 1F).

\section{Results and Discussion}

Results indicated that micropropagation of wild chilean strawberry can be done effectively using the protocol describe above. The changes introduced in this procedure allowed to reduce in $50 \%$ the multiplication, rooting and aclimatation period and reduce the cost of chemicals and labor during this work. Specifically, 1) the sterilization protocol was very effective in removing contaminants from plant material; thus, the contamination rate was $<5 \%$; 2) the establishment of the buds took 4 weeks and generated $80 \%$ of the healthy plantlets; 3) the multiplication stage lasted 3 weeks and obtained an average rate of 15 plantlets per bud; with less than eight subcultures; 4) The elongation and rooting stages took about 2 and 3 weeks, respectively, and the survival rate under greenhouse conditions was $95 \%$. Finally, this procedure allowed to produce 10.000 plants for field evaluation and commercial purposes.

\section{Literature Cited}

Boxus, Ph. 1998. Micropropagation of strawberry via axillary shoot proliferation, p.103-114. In:
Fig. 1. Stages of in vitro micropropagation in Fragaria chiloensis.

R.D. Hall (ed.). Methods in molecular biology. vol. 111. Plant cell culture protocols. Hummana Press Inc. Totowa. N.J.

Boxus, Ph., A. Jemmali, J.M. Terzi, and O. Orezki. 2000 . Drift in genetic stability in micropropagation: the case of strawberry. Acta Hort. 530:155-161.

Cameron, J., T. Sjulin, J. Ballington, C. Shanks, and C. Muñoz. 1993. Exploration, collection and evaluation of Chilean Fragaria: Summary of 1990 and 1993 expeditions. Acta Hort. 348:65-74.

Crock, J.E., C. Shanks, and B. Barritt. 1982. Resistance in Fragaria chiloensis and Fragaria $\times$ ananasa to the aphids Chaetosiphon fragaefolli and C. thomasi. HortScience 17:959-960.

Damiano, C., A.Ascarelli, A. Frattarelli, and P. Lauri. 1995. Adventious regeneration and genetic variability in strawberry. Acta Hort. 392:107-114.

Daubeny, H.A. and H.S. Pepin. 1965. The relative resistance of various $F$. chiloensis clones to Phytophtora fragaria. Can. J. Plant Sci. 45:365-368.

Hancock, J., A. Lavín, and J. Retamales. 1999. Our Southern strawberry heritage: Fragaria chiloensis of Chile. HortScience 34:814-816.

Jungnickel, F. 1988. Stawberries (Fragaria spp. and hybrids), p. 38-103. In: Y.P.S. Bajaj (ed.). Biotechnology in agriculture and forestry. vol. 6 . Crops II. Springer-Verlag Berlin, Heidelberg.

Shanks, C. and B. Baritt. 1974. Fragaria chiloensis clones resistant to the stawberry aphid. HortScience 9:202-203.

Rosati, P. 1993. Recent trends in strawberry production and research: An overview. Acta Hort. 348:23-44. 